\title{
Evaluating your collection to facilitate literacy
}

Everhart, Nancy;Bishop, Kay

International Association of School Librarianship. Selected Papers from the ... Annual Conference; 2000;

Education Database

pg. 179

Information Literacy: Key to the Future

\section{Evaluating Your Collection to Facilitate Literacy}

\author{
Nancy Everhart
}

\author{
Assistant Professor \\ Division of Library and Information Science \\ St. John's University \\ United States of America
}

\section{Kay Bishop}

Associate Director

School of Library and Information Science

University of South Florida

United States of America

How can we evaluate a library collection to facilitate literacy? Before we can effectively answer this question we first need to look at the terms "collection" and "literacy." The meanings of both of these terms, particularly as they relate to school librarianship, have evolved in the past several years.

\section{What Is a Collection?}

Traditionally a collection has referred to print items that were housed in a single site, the school library. In the past several years, however, school libraries have added other formats of information, including both print and non-print items. Print items are not only books but also newspapers, magazines, and pamphlets; non-print items may include videocassettes, audiocassettes, CD-ROMs, kits, picture files, computer software programs, websites, and DVDs. Thus, the variety of formats included in a library collection has grown significantly.

Not only have the formats themselves increased but now our means of accessing the resources have also become greater in number. The school library collection is no longer just those items that are housed within the four walls of a room; we can now reach out to access materials that are housed in other local, state, and international libraries as well as other types of information centers or sites. Through interlibrary loan, cooperative agreements, and the use of electronic access, those who use a school library can obtain a huge number of materials in numerous formats. When we evaluate our collections to facilitate literacy, we must also consider the evaluation of both on-site and off-site materials, particularly the items accessed through the Internet. 


\section{What Is Literacy?}

The term "literacy" has changed even more than "collection." One hundred years ago literacy referred to the ability to sign one's name and to recite from familiar texts such as the Bible or a school textbook. Even twenty years ago literacy was primarily linked to the reading of print materials. Today, the concepts of literacy have been applied to so many areas that the term has become extremely confusing. Functional literacy, basic literacy, environmental literacy, business literacy, cultural literacy, and information literacy are just a few of the literacy-linked terms that we hear. It is probably safe to assume that laypersons outside a particular discipline have little understanding of these concepts. Even persons within a discipline may not even have a common understanding of a certain term referring to literacy. This is particularly true of "information literacy," which is the term in school librarianship. Although school librarians themselves are beginning to understand the many facets of "information literacy," it does not necessarily follow that school administrators and teachers have similar understandings.

We all want our students to be information literate, but what does that involve? Information literacy means having the skills to

- Recognize the need for information

- Identify and locate information sources

- Access information in those sources

- Evaluate the quality of information obtained

- Organize and synthesize the information

- Use the information effectively

- $\quad$ Produce new information

Information literacy is thus a process. Carol Kuhlthau's studies (1985, 1987, 1988, 1993), which deal with the cognitive and affective stages that students follow to solve a problem or to research a topic, have contributed greatly to the understanding of the process involved with becoming information literate. Her studies also point out the need for students to use information in constructing their own knowledge.

\section{How Do Standards and Policies Address School Library Collections and Information Literacy?}

Almost all library standards and policies written in the past several years have addressed the concept of information literacy and the expanded concept of a library collection. In preparing for our presentation, we looked at some of these standards, and we will share brief statements from three such documents:

- Information Power: Building Partnerships for Learning (the national school library guidelines produced by the American Association of School Librarians and the Association for Educational Communications and Technology)

- "Libraries in New South Wales Government Schools Policy Statement" (a department of education school library policy from New South Wales, Australia)

- "IFLA/UNESCO School Library Manifesto" (a document produced by the International Federation of Library Associations and Institutions) 


\section{A Book: Information Power: Building Partnerships for Learning}

This book is perhaps the most widely cited document dealing with information literacy, particularly as it relates to student learning. It addresses a school library collection in the section that deals with the mission and goals of a media center:

To provide a physical access to information through

1. a carefully selected and systematically local collection of diverse learning resources that represent a wide range of subjects, levels of difficulty, and formats;

2. a systematic procedure for acquiring information and materials from outside the library media center and the school through such mechanisms as electronic networks, interlibrary loan, and cooperative agreements with other information agencies; and instruction in using a range of equipment for accessing local and remote information in any format. (American Association of School Librarians 1998, 7)

Nine information literacy standards for student learning are described. The three that deal directly with the concept of information literacy are

\footnotetext{
Standard 1: The student who is information literate accesses information efficiently and effectively.

Standard 2: The student who is information literate evaluates information critically and competently.

Standard 3: The student who is information literate uses information accurately and creatively. (American Association of School Librarians 1998, 8)
}

\section{A Policy Statement: "Libraries in New South Wales Government Schools"}

This general policy provides a basis for school libraries in New South Wales to develop more detailed descriptions of their individual services and programs. The school library collection and its relationship to student learning is described as follows:
School library collections should contain materials and equipment in a wide variety of forms suited to learning processes. Materials are those processed items that contain data and information and typically include audiovisual items, models and games as well as books, pamphlets, newspapers and magazines. Increasingly, materials now include computer software, toys and artefacts [sic]. Publications of the New South Wales Department of Education such as curriculum documents, journals and serials must be accessible through the library and be available for loan. (New South Wales Department of Education 1999,4)

Information literacy and its relationship to student learning is addressed in the following section of the policy statement:

\footnotetext{
The purpose of the school library is to enhance teaching and students' learning within the total school program by ...

- providing opportunities for students to develop information skills and use them competently and confidently

- extending and enlivening students' learning experiences and enriching their lives through the effective use of resources

- providing experiences to stimulate reading and develop in students a desire to read.... (New South Wales Department of Education 1999, 2)
}

A Document: "IFLA/UNESCO School Library Manifesto" 
This document, which was ratified by the $30^{\text {th }}$ United Nations Educational, Scientific and Cultural Organization General Conference, describes the mission, the goals, staffing, and the operation and management of a school library. It also contains a statement dealing with funding legislation and networks. Plans include translating the publication into as many languages as possible.

The relationship of a school library collection and learners is described in the Manifesto's mission statement of the school library: "The school library offers learning services, books and resources that enable all members of the school community to become critical thinkers and effective users of information in all formats and media" (International Federation of Library Associations and Institutions 1999, 15).

The mission statement also addresses information literacy, relating it to student achievement: "It has been demonstrated that, when librarians and teachers work together, students achieve higher levels of literacy, reading, learning, problem-solving and information and communication technology skills" (International Federation of Library Associations and Institutions 1999, 15).

\section{How Is the Collection Evaluated?}

What is the bridge between literacy and evaluation of the collection? There are several. First, the school library collection should support the school's literacy efforts. Second, research has shown a correlation between students' literacy achievement and the quality of their school libraries (Hamilton-Pennell et al., 2000). Third, "information literacy" covers a wide range of behaviors of interacting with collections. And fourth, we are increasingly being asked to justify the need for school libraries.

Although each person will have their own unique reasons for evaluating their collections, the same process should be followed. The first step is to determine your goals or to define the problem you are trying to solve. The second step is to ascertain the kinds of data that need to be collected to make judgments about those goals or problems. The third step is to identify a method to collect that data, and the fourth is to analyze the data you collect. Finally, it is important to convey the results to the appropriate party.

Various methods can be used to evaluate a collection, but they all break down into two major types of measures: quantitative and qualitative measures. Quantitative evaluation measures how many. Qualitative measures how good is the collection or whether the collection is appropriate for the users. There are forms in the handouts that address both types of techniques.

\section{Size of the Collection}

A simple way to evaluate the collection is by size. How many items are in the collection? Most automated circulation systems have a reporting option for the total number of items that have been entered into the system. If you do not have an automated system you can use the "holdings estimation worksheet" included in the handouts. Use a ruler, your shelf list, and the form. Take ten 1-inch samples from various parts of the collection. Count the number of cards per inch and the number of volumes per card. Average the samples together to get the average number of cards per inch and average number of volumes per inch. Follow the steps on the form to determine the total library holdings. 
The advantage of using collection size as an evaluative criterion is that the data is straightforward and easily understood. But does quantity indicate quality? Sometimes it does, but not always. It is possible to have a large collection of useless, old, and worn materials. Which is more useful, unique titles or number of volumes? Absolute size or rate of growth?

After you collect this data you can compare it to various guidelines. One example in the handout is from the Pennsylvania Department of Education for minimum, average, and exemplary sizes of collections. Notice that the guidelines state "currently useful volumes."

\section{Usage of the Collection}

Circulation is the most common statistic kept in school libraries. It is meaningless to use circulation measures for evaluation, however, if you limit how many items students can check out in conjunction with a fixed schedule; the numbers will never fluctuate.

In the handouts, there are some statistics that use circulation measures, but interpret them differently. The "relative use factor" is the ratio of circulation to holdings, and it is a good way to compare the usage of various areas of the collection. A relative use of 1.00 indicates that a given area of the collection is being used in direct proportion to the number of items available. A relative use of less than 1.00 indicates that there is less usage, and more than 1.00 means more usage in that area of the collection. Areas of the collection with high relative use factors can be strengthened and those with low factors more heavily promoted. The relative use factor can be calculated manually but is more readily available with automated systems.

Circulation per student and turnover rate are measures that are easily understood by administrators and can capsulize your circulation for a year. Circulation per student indicates the number of items the average student takes out per year. It is calculated by dividing the total annual circulation by the total number of students in the school. Turnover rate indicates how many times each item was used. To determine turnover rate divide the annual circulation by the total library holdings.

Keep in mind that these figures are averages. There will be students who take out many materials and those who take out none. There will be books that have high circulation and those that have none. Is there an absolute number to aim for with either measure? None have been determined. The value of the measures are to compare your library over time or maybe to compare your library to similar libraries in your region.

\section{Percentages of the Collection Found in Standard Sources}

If a high percentage of the library's titles are found in standard sources, it may be assumed the collection is of high quality. What are some of these "standard sources?" Best books lists (some are listed in the bibliography) and selection sources such as the High School Catalog and The Elementary School Library Collection qualify. The advantages of this type of comparison are that such lists are readily available and areas of the collection needing development can be identified. Disadvantages are the use of arbitrary samples, quickly outdated sources, and the irrelevance of the titles listed to the library or its users. It also assumes a "core collection" for every library. It is not necessary to check every item in the collection when using this method. You can sample every $10^{\text {th }}, 20^{\text {th }}$, or $30^{\text {th }}$ book against the source. For small "best books" lists you can review the entire list. 


\section{Examining the Collection Directly}

Why not just go to the shelves and evaluate what is there? There are advantages: it is practical, you get immediate results, it is useful for assessing condition, and it is good for examining accessibility. The disadvantages are that it often requires a subject expert in certain areas, it is more subjective than scientific, and it can be time consuming. Van Orden (1995) and Everhart (1998) provide guidelines for direct examination, which is often used in conjunction with weeding a collection.

\section{User Opinions of the Collection}

Students and faculty are the users of the school library's collection. There are numerous ways to get their opinions: interviews (good for children), focus groups (a representative sampling), and surveys. In the handout are sample surveys for students and faculty that focus on collection. These were taken from Everhart's (1998) book. Advantages of user opinion are that users are often knowledgeable about specific areas and you can get to the heart of the matter being studied, especially with interviews. The disadvantages of these methods are that they can be time consuming, they may provide primarily impressionistic responses, and users' interests and opinions may be too narrow to reflect the library's complete collection development policy.

\section{In-house Use of the Collection}

Materials are often used in the library, but this use cannot be recorded with traditional circulation measures. Some methods of measuring in-house use are examining or scanning materials left on tables and desks, interviewing patrons, observing, and leaving survey forms in books.

The use of electronic resources is a major concern in all types of libraries because traditional circulation is going down. As students increase their use of electronic sources it becomes ultimately more important to evaluate how well the "library collection," whatever that definition might entail, meets particular needs rather than how many items reside on the shelves in a particular subject. Since electronic sources won't be checked out you have to use alternative evaluation techniques such as observation, computer reporting options, and examination of student work.

One of the major problems with circulation statistics is that there is no way of knowing whether or not the materials taken out actually reflect what the user wanted or if electronic sources are being used to satisfy a need. In order to ascertain this, users must be interviewed to see if they found what they wanted. The resulting statistic, called the "fill rate," is defined as the percentage of successful searches for library materials in any part of the library collection, and it is calculated by dividing the number of successful searches by all searches. Sample fill rate survey and tabulation forms are included in the handouts.

\section{Conclusion}

There are numerous methods of evaluating a collection. The most effective evaluation uses a combination of qualitative and quantitative methods. Once an evaluation is completed, it is important that you use the data obtained to make both short- and long- 
range plans and that you report the results to the appropriate people. We hope that through this presentation you have obtained some helpful ideas to evaluate your collection to facilitate literacy and improve opportunities for student learning.

\section{Bibliography}

American Association of School Librarians \& Association for Educational Communications and Technology. (1998). Information Power: Guidelines for school library media programs. Chicago: American Library Association.

Everhart, N.L. (1998). Evaluating the school library media center: Analysis techniques and research practices. Englewood, $\mathrm{CO}$ : Libraries Unlimited.

Hamilton-Pennell, C., Lance, K.C., Rodney, M.J., \& Hainer, E. (2000). Dick and Jane go to the head of the class." Available on-line: http://www.slj.com/articles/articles/20000401 7475.asp (Accessed July 20. 2000)

International Federation of Library Associations and Institutions. (1999). IASL Newsletter, 28 (December), $15-16$

Kuhlthau, C.C. (1985). A process approach to library skills. School Library Media Quarterly, 14(Winter), $35-40$.

Kuhlthau, C.C. (1987). An emerging theory of library instruction. School Library Media Quarterly, 16(Winter), 23-28.

Kuhlthau, C.C. (1988). Developing a model of the library search process: Cognitive and affective aspects. Research Quarterly, 37 (Winter), 232-42.

Kuhlthau, C.C. (1993). Seeking meaning: A process approach to library and information services. Norwood, NJ: Ablex.

New South Wales Department of Education. (1999). Libraries in New South Wales government schools Available on-line: http://www.dse.nsw.edu.au/sstaff/F1.0/F1.8/resources/libraries.htm (Accessed July 20, 2000).

Van Orden, P. (1995). The collection program in schools: Concepts, practices, and information sources. Englewood, CO: Libraries Unlimited. 


\section{HANDOUTS}

Available: www.cas.usf.edu/lis/sweden

\section{Bibliography}

\section{Books}

Collection Evaluation Techniques: A Short, Selective, Practical, Current, Annotated Bibliography, 1990-1998. Edited by Bonnie Strohl. American Library Association, 1999.

Doll, Carol A. and Pamela P. Barron, Collection Analysis for the School Library Media Center. American Library Association, 1991.

Everhart, Nancy L. Evaluating the School Library Media Center: Analysis Techniques and Research Practices. Libraries Unlimited, 1998.

Kachel, Debra E. Collection Assessment and Management for School Libraries. Greenwood, 1997.

Lancaster, F.Wilfrid. If You Want to Evaluate your Library. University of Illinois, 1993.

Loertscher, David V. Collection Mapping in the LMC : Building Library Media Center Collections in the Age of Technology. Hi Willow Research and Publishing, 1996.

Loertscher, David V. Taxonomies of the School Library Media Program. Libraries Unlimited, 1988.

Van House, Nancy A., Mary Jo Lynch, Charles R. McClure, Douglas L. Zweizig, , and Eleanor J. Rodger. Output Measures for Public Libraries: A Manual of Standardized Procedures. 2nd. ed. Chicago: American Library Association, 1987.

Van Orden, Phyllis. The Collection Program in Schools : Concepts, Practices, and Information Sources. Libraries Unlimited, 1995.

Walter, Virginia A. Output Measures for Public Library Service to Children. American Library Association, Association for Library Service to Children, 1992.

Yesner, Bernice L. and Hilda L. Jay. The School Administrator's Guide to Evaluating Library Media Programs. Shoestring Press, 1987.

\section{Periodical articles}

Bertland, Linda H. "Circulation Analysis as a Tool for Collection Development." School Library Media Quarterly 19:2. (Winter 1991) 90-97.

Callison, Daniel. "A Review of the Research Related to School Library Media Collections: Part I." School Library Media Quarterly 19:1. (Fall 1990) 57-62. 
Callison, Daniel. "A Review of the Research Related to School Library Media Collections: Part II." School Library Media Quarterly 19:2. (Winter 1991) 117-21.

Doll, Carol A. "Quality and Elementary School Library Media Collections." School Library Media Quarterly 25:2. (Winter 1997) 95-102.

Miller, Marilyn and Marilyn Shontz, "How Do You Measure Up?" School Library Journal 45: 10. (October 1999) 50-59.

\section{Websites}

Australian Libraries Gateway: Collection Assessment: Tools and References www.nla.gov.au/libraries/help/catr.html

Australian Libraries Gateway: A Guide to the Collection Assessment Process www.nla.gov.au/libraries/help/guide.html

Best Books of the Year: A Roundup of Annual Book Lists Published on the Web (Children's Literature Web Guide)

www.acs.ucalgary.ca/ dkbrown/bestbooks.html

International Reading Association - Choices Booklists www.reading.org/choices/

The Internet Public Library Book Lists \& Awards Reference www.ipl.org/ref/RR/static/hum6200.html

Recommended Book Lists (Children's Literature Web Guide) www.acs.ucalgary.ca/ dkbrown/lists.html

YALSA Booklists

www.ala.org/yalsa/booklists 


\section{HOLDINGS ESTIMATION WORKSHEET}

\section{Cards per inch Vols. per card}

1. Take ten one-inch samples from the shelflist.

For each sample count:

(a) cards per inch

(b) volumes per card

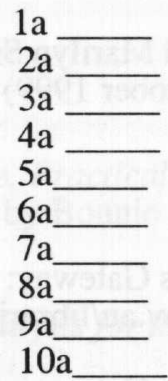

b

b

b

b

b

b

b

b

b

b

2. Average together the ten samples to get:

$2 c$

d

(c) Average number of cards per inch

(d) Average number of volumes per inch

3. Measure the entire shelflist for total shelflist inches

4. Multiply the average number of cards per inch (2c) by the total shelflist inches (3) = Estimated number of cards in shelflist

5. Multiply the average number of volumes per card 5 (2d) by estimated number of cards in shelflist (4). Result is estimated number of volumes in shelflist.

6. Enter number of items for any materials not

6 included in the shelflist.

7. Add (5) + (6) for TOTAL LIBRARY HOLDINGS 


\section{PERCENTAGES OF THE COLLECTION IN STANDARD SOURCES}

\section{Source Title}
a. Number of books in sample
b. Number of these titles found in source
c. Percent of titles found in source (bX100)/a

\section{QUANTITATIVE MEASURES OF BOOK COLLECTION}

(Pennsylvania Department of Education)

\begin{abstract}
Minimum
10 currently useful volumes/ pupil or 2,000 volumes, whichever is greater
\end{abstract}

Average

15 currently useful volumes/ pupil or 8,000 volumes, whichever is greater

\section{Exemplary}

$$
\begin{array}{r}
20 \text { currently } \\
\text { useful volumes/ } \\
\text { pupil or } 14,000 \\
\text { volumes, which- } \\
\text { ever is greater }
\end{array}
$$

\section{USAGE OF THE COLLECTION MEASURES}

Relative Use Factor $=$ Percent of Circulation

Percent of Collection Responsible for that Circulation

Percent of Collection Responsible $=\underset{\text { Number of Items in That Class }}{\text { for that Circulation }}$
Total Number of Items in Collection

Circulation Per Student $=$ Annual Circulation

Number of Students in School

Turnover Rate $=\underline{\text { Annual Circulation }}$

Total Library Holdings 


\section{STUDENT LIBRARY MEDIA CENTER COLLECTION SURVEY}

\section{RATE THE LIBRARY MEDIA CENTER COLLECTION IN THE FOLLOWING AREAS}

Non-fiction books

$\begin{array}{cccc}\text { Excellent } & \text { Good } & \text { Fair } & \text { Poor } \\ 4 & 3 & 2 & 1 \\ 4 & 3 & 2 & 1 \\ 4 & 3 & 2 & 1 \\ 4 & 3 & 2 & 1 \\ 4 & 3 & 2 & 1 \\ 4 & 3 & 2 & 1 \\ 4 & 3 & 2 & 1 \\ 4 & 3 & 2 & 1 \\ 4 & 3 & 2 & 1 \\ 4 & 3 & 2 & 1 \\ 4 & 3 & 2 & 1 \\ 4 & 3 & 2 & 1 \\ 4 & 3 & 2 & 1 \\ 4 & 3 & 2 & 1 \\ 4 & 3 & 2 & 1\end{array}$

\section{INDICATE YOUR LEVEL OF AGREEMENT WITH THE FOLLOWING STATEMENTS:}

It is easy to locate materials in the media center.

The media center collection is up to date.

The media center collection is attractive.

Materials in the collection are interesting.

There are enough materials in the media center.
Strongly agree

Strongly agree

Strongly agree

Strongly agree

Strongly agree
Agree

Agree

Agree

Agree

Agree
Disagree

Disagree

Disagree

Disagree

Disagree
Strongly disagree

Strongly disagree

Strongly disagree

Strongly disagree

Strongly disagree

The library media center should buy the following:

What improvements in the collection or access to information would you find most useful? 


\section{FACULTY LIBRARY MEDIA CENTER COLLECTION SURVEY}

\section{RATE THE LIBRARY MEDIA CENTER COLLECTION IN THE FOLLOWING AREAS:}

Non-fiction books Excellent Good Fair Poor

Fiction books

Paperbacks

Newspapers

Magazines

Encyclopedias

Reference Books

CD-ROMs

Online/Internet Resources

Audiovisual Materials

Computer Software

Vertical File

Professional Collection

Microfilm/microfiche

Materials for my teaching areas

Materials for my personal interests

$\begin{array}{llll}4 & 3 & 2 & 1 \\ 4 & 3 & 2 & 1 \\ 4 & 3 & 2 & 1 \\ 4 & 3 & 2 & 1 \\ 4 & 3 & 2 & 1 \\ 4 & 3 & 2 & 1 \\ 4 & 3 & 2 & 1 \\ 4 & 3 & 2 & 1 \\ 4 & 3 & 2 & 1 \\ 4 & 3 & 2 & 1 \\ 4 & 3 & 2 & 1 \\ 4 & 3 & 2 & 1 \\ 4 & 3 & 2 & 1 \\ 4 & 3 & 2 & 1 \\ 4 & 3 & 2 & 1 \\ 4 & 3 & 2 & 1\end{array}$

INDICATE YOUR LEVEL OF AGREEMENT WITH THE FOLLOWING STATEMENTS:

I have adequate input into collection purchases.

There is adequate publicity about new purchases.

There are enough materials in the media center.

Materials in the collection are interesting.

\section{Strongly agree}

Strongly agree

Strongly agree

Strongly agree
Agree

Agree

Agree

Agree
Disagree

Disagree

Disagree

Disagree
Strongly disagree

Strongly disagree

Strongly disagree

Strongly disagree

The library media center should buy the following:

What improvements in the collection or access to information would you find most useful?

191 


\section{FILL RATE SURVEY}

Form \#

1. How old are you?

2. Were you looking for anything special in the library? YES NO Please tell what you were looking for:

a.

Did you find it? YES NO

b.

Did you find it? YES NO N

c.

Did you find it? YES NO

3. If you were just browsing and not looking for anything special, did you find anything interesting? YES NO

4. Is there anything else you want to tell us about the library? You may write on the back of the page if you want to.

Thank you for answering our questions. Please leave this form with the library media specialist today. 


\section{LIBRARY FILL RATE}

\section{TABULATION AND CALCULATION FORM}

\begin{tabular}{|l|l|l|l|l|}
\hline \multicolumn{2}{|l|}{ TITLE, SUBJECT, AUTHOR (1) } & \multicolumn{2}{c|}{ BROWSING (2) } \\
Form Number $\quad$ Found (a) & Bot found (b) & Browsers (a) & Found Something (b) \\
\hline & & & & \\
\hline & & & & \\
\hline & & & & \\
\hline TOTALS & & & & \\
& & & & \\
\hline
\end{tabular}

1. Title/subject/authors sought (total of columns la and 1b)

2. Title/subject/authors found (total of column 1a)

3. Title/subject/authors fill rate (line 2 divided by line 1)

4. Number of browsers (total of column 2a)

5. Number of browsers finding something (total of column $2 b$ )

6. Browsing fill rate (line 5 divided by line 4 )

7. Total fill rate (total of lines 2 and 5 divided by total of lines 1 and 4 )

Note: Form should be extended to include additional form numbers and results. 